\title{
Decline of large-diameter trees in a bamboo-dominated forest following anthropogenic disturbances in southwestern Amazonia
}

\author{
Leonardo G. Ziccardi ${ }^{1,2}$ (D) Paulo Maurício Lima de Alencastro Graça ${ }^{1} \cdot$ Evandro O. Figueiredo $^{3} \cdot$ Philip M. Fearnside $^{1}$
}

Received: 3 May 2019 / Accepted: 17 November 2019 / Published online: 11 December 2019

(C) INRA and Springer-Verlag France SAS, part of Springer Nature 2019

\begin{abstract}
- Key message Reduction in the aboveground biomass of larger trees is the main consequence of disturbances in open forests dominated by bamboo. Because these trees are of central importance both for ecosystem function and for the economic value of the forest for management, the impact on these trees due to the increase of bamboo abundance following anthropogenic disturbances is both an environmental and a commercial concern.

- Context Bamboo-dominated forests in southwestern Amazonia are increasingly exposed to the combined impacts of fire and selective logging. Although the climbing bamboos (Guadua spp.) are considered native species of these forests, disturbances contribute to a discontinuous canopy, which is an ideal scenario for an increase in abundance of these opportunistic plants. The regeneration of tree biomass is limited in these cases, decreasing the carbon stock of the forest.

- Aims This study compares changes in bamboo abundance and forest structure in the face of forest fire and post-burn logging in the municipality (county) of Rio Branco, Acre state, Brazil.

- Methods The study was conducted on the Transacreana Highway (AC 090) in the eastern portion of Acre state, Brazil. We compared changes in bamboo abundance and aboveground biomass (AGB) of an area of forest with no known recent disturbances to areas in the same forest that had been disturbed by fire and post-burn logging, which are frequent sources of disturbance in this region. The live and dead AGB values were estimated by field inventory in 2016, which was 11 years after a fire and 9 years after selective logging. The AGB values for trees and palms were estimated by allometric equations in three 2-ha areas. Bamboo abundance was expressed both by bamboo biomass $\left(\mathrm{Mg} \mathrm{ha}^{-1}\right)$ and culm density $\left(\right.$ culms ha ${ }^{-1}$ ), sampled by direct measurements in three $200-\mathrm{m}^{2}$ areas.

- Results Bamboo abundance was over 20\% higher in forest that had been burned but not logged, as compared to undisturbed forest. Compared to undisturbed plots, aboveground forest biomass (live + dead) was $34 \%$ lower in plots exposed to fire but not logging, and 36\% lower if exposed to both. Live trees and palms represented $77 \%$ of the total forest biomass (live + dead), and almost a half of this contribution (41\%) was in individuals in the largest diameter class (diameter at breast height $>50 \mathrm{~cm}$ ).

- Conclusion Increase in the level of impact led to a reduction in aboveground carbon stock of the forest. One of the main consequences of disturbances in open forests dominated by bamboo is reduction of live trees and palms, especially in the diameter at breast height (DBH) class over $50 \mathrm{~cm}$.
\end{abstract}

Keywords Brazil $\cdot$ Acre $\cdot$ Bamboo forest $\cdot$ Guadua spp. · Forest fires $\cdot$ Logging

Handling Editor: Paulo Fernandes

Contributions LGZ designed the study and conducted the fieldwork, data analysis and writing. PMLAG, EOF and PMF contributed to the project design, data interpretation and writing

Leonardo G. Ziccardi

leonardo.g.ziccardi@gmail.com

1 Department of Environmental Dynamics, National Institute for Research in Amazonia (INPA), Av. André Araújo, 2936, CEP 69067-375, Manaus, Amazonas, Brazil
2 Department of Forestry, Michigan State University, East Lansing, MI 48824, USA

3 Embrapa Acre, Rodovia BR-364, km 14, CEP 69900-056, Rio Branco, Acre, Brazil 


\section{Introduction}

Forest fires are not common natural events in the Amazon rainforest. The only known natural cause of forest fires is lightning strikes, and in humid tropical forests, burning is almost always limited to a single tree or a very small patch of vegetation (Fearnside 1990). In contrast, forest fires from human ignition are increasingly frequent sources of disturbance.

Fire occurrences are directly related to the vegetation type, climatic conditions and socioeconomic context of a given region. Even at different time scales, a strong relationship persists between the fire regime and the territorial dynamics (Molina and Galiana-Martín 2016). Logging is an example of human activity that determines forest-fire susceptibility. Logging roads and the gaps formed by felling trees promote the opening of the canopy, contributing to an increase in the probability of occurrence of forest fires (Nepstad et al. 1999).

An important reflection of anthropogenic disturbances can be observed in the open forests of southwestern Amazonia. These forests occupy an estimated area of at least $161,500 \mathrm{~km}^{2}$ and are characterized by the dominance of native bamboo species of the genus Guadua in the understory. Although the occurrence of Guadua spp.in the Amazon is naturally associated with luvisols (Kandisols) and eutrophic cambisols (Inceptisols), disturbance in the forest can promote clearings favorable to Guadua spp., creating conditions for it to occur in areas where it would not otherwise exist (de Carvalho et al. 2013; Ferreira 2014). Forests of southwestern Amazonia subject to disturbances such as windthrows, logging, and fire are characterized by a discontinuous canopy that provides ideal conditions for invasion of aggressive pioneering plants, such as bamboo.

Open bamboo-dominated forests have a reduced number of trees in the largest diameter classes when compared to forests where bamboo does not occur, which promotes a reduction in total aboveground biomass, carbon stock, and, consequently, in the economic value of these forests (Oliveira 2000; Nelson et al. 2001). Avoiding degradation in these forests is essential for the continuity of important ecosystem services (ES), such as hydrological regulation, maintenance of biodiversity, and carbon stock (Daily 1997).

Logging is not likely to decrease in the near future in Brazil, given the new presidential administration's dramatic shift toward less environmental regulation and more promotion of extractive activities (Ferrante and Fearnside 2019). Logging has been shown to form gaps by removal of large trees from the forest. These gaps provide favorable conditions for native climbing bamboo, often starting a self-perpetuating disturbance cycle where these bamboos hang on the trees, causing physical damage to the their crowns and promoting greater canopy opening, which is a favorable scenario for the development of more ramets (Griscom and Ashton 2006). Thus, regeneration of tree species of commercial value becomes limited (D’Oliveira et al. 2013; Rockwell et al. 2014).

Occurrence of forest fires is critical under these circumstances, because an increase in tree mortality, in bamboo dominance, and in dead biomass (necromass) provides fuel for future fire events (Smith and Nelson 2011; Veldman and Putz 2011). Intensification of climate change, with effects such as more-frequent extreme droughts, and increases in other direct human impacts, such as selective logging, is consistent with the observed progressive increase in the number of forest fires and of the gaps that are left as a legacy of these disturbances killing trees and palms, enhancing bamboo density in these forests (Lewis et al. 2011; Ferreira 2014).

The increase in culm density per unit area may not necessarily reflect a direct increase in bamboo biomass. Culms tend to lose verticality in forests with reduced numbers of large trees, where bamboo becomes locally dominant and has diameter increments of ramets restricted by limited access to light (Yavit 2017). This scenario of bamboo dominance in a forest leads to alterations in the floristic composition, reducing the number of species in a single hectare by almost $40 \%$, on average (Silveira 2005).

An important first step to reduce degradation effects in these forests is to better understand and quantify the impacts associated with the main sources of disturbance. This paper aims to help fill an important gap in knowledge of the effect of fire and post-burn logging on the structure and composition of forests dominated by Guadua spp. in the understory. Here, we investigate how these disturbances affect the dominance of bamboo, aboveground forest biomass, and abundance of large trees in southwestern Amazon forests.

\section{Materials and methods}

\subsection{Study area}

The study area is located in the eastern portion of Acre State on the Transacreana Highway (AC 090), $45 \mathrm{~km}$ from the city of Rio Branco $\left(9^{\circ} 59^{\prime} 10^{\prime \prime} \mathrm{S} ; 68^{\circ} 11^{\prime} 33^{\prime \prime} \mathrm{W}\right)$. The municipality (county) of Rio Branco has an area of $8835.5 \mathrm{~km}^{2}$ and an estimated population of 383,443 (Brazil, IBGE, 2017). The region has an annual average temperature of $25.6^{\circ} \mathrm{C}$ and receives mean annual precipitation of approximately $2200 \mathrm{~mm}$ (Sombroek 2001). The rainy season usually begins in October and lasts until May. The rainiest quarter comprises the months of January, February, and March, while the driest quarter corresponds to June, July, and August (Acre, Governo do Estado 2000).

Two areas were selected in the same forest remnant, both disturbed by the same forest fire in 2005. One of the areas was further disturbed by logging in 2007 (logging intensity $16.82 \mathrm{~m}^{3} \mathrm{ha}^{-1}$ ). Based on the $0.54 \mathrm{~g} \mathrm{~cm}^{-3}$ average wood density value in this part of Amazonia (Nogueira et al. 


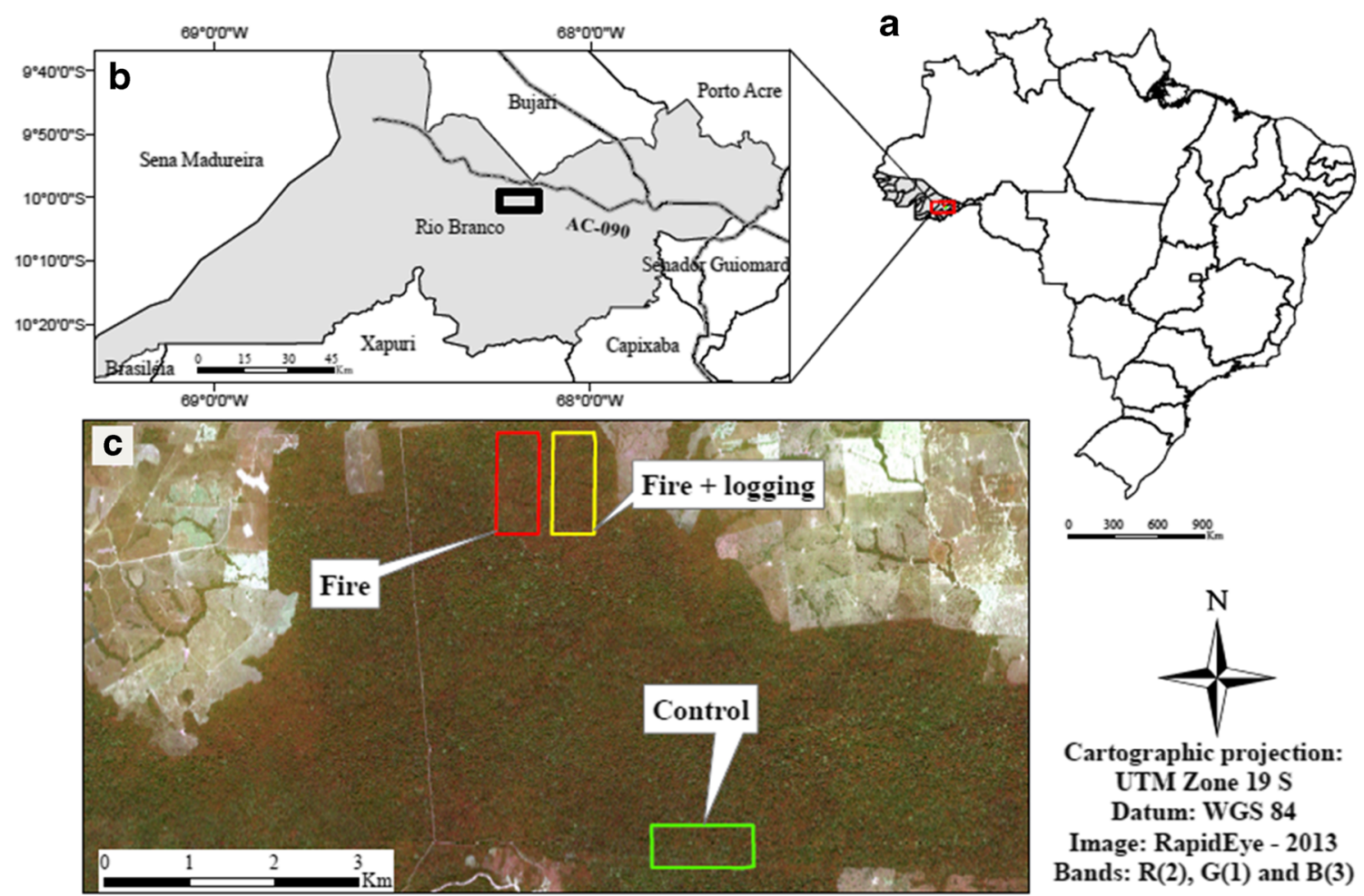

Fig. 1 Location map of study areas (c) in the municipality of Rio Branco (b), Brazil (a)

2007), the loss of wood biomass after logging was $10.16 \mathrm{Mg} \mathrm{ha}^{-1}$. In this same remnant, approximately $4 \mathrm{~km}$ to the south of the first two areas, we selected an area used as reference (control) that was not affected by fires or by recent extractive processes (Fig. 1).

According to local residents, most of the forests in the region were disturbed by forest fires in 2005. A major drought occurred in 2005 in this part of Amazonia (da Silva et al. 2018; Vasconcelos et al. 2013), and the many cattle ranches along the AC-90 Highway probably also contributed to the widespread fires. The increase of the density of bamboo in the forest was subsequent to these fires.

\subsection{Sampling design}

The study was carried out along three transects, each $1100 \mathrm{~m}$ in length (one for each treatment). Placement of transects respected a minimum distance of $100 \mathrm{~m}$ from the edge of the forest. Along each transect, 8 plots of $50 \times 50 \mathrm{~m}$ were systematically placed at 100-m intervals, summing 2 ha as the sample area for estimating aboveground biomass in each treatment (Fig. 2).

Bamboo biomass was obtained directly in 8 subplots of $5 \times$ $5 \mathrm{~m}\left(25 \mathrm{~m}^{2}\right)$, installed systematically, totaling a sample area of $200 \mathrm{~m}^{2}$ for each treatment.

\subsection{Aboveground biomass}

Aboveground biomass was estimated by summing live and dead biomass (necromass) classes. All values referring to estimates of live and dead biomass of trees and palms were obtained by allometric equations developed for the Amazon region. Bamboo biomass was obtained by direct weighing. Woody residues were estimated by line-intercept transects (Van Wagner 1968) (Table 1).

\subsubsection{Live trees and palms}

For aboveground biomass estimation of live trees, we used the equation developed for forests located in the "arc of deforesta-
Fig. 2 Schematic of the sampling design in each transect of $1100 \mathrm{~m}$ in length

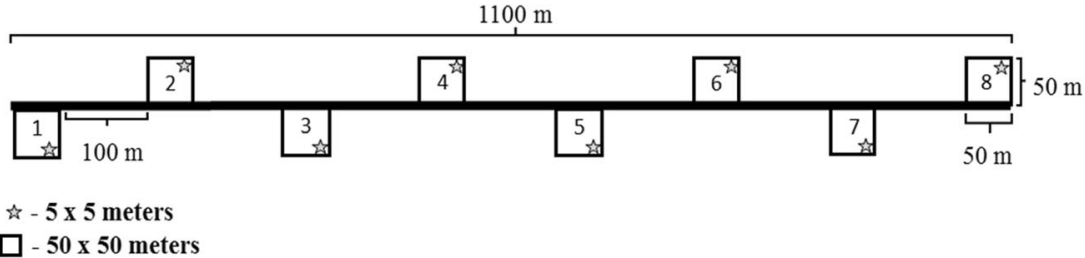


Table 1 Allometric equations and methods used to estimate biomass in each compartment

\begin{tabular}{lll}
\hline Compartment & Equation $/$ method & Author \\
\hline Live trees $(\mathrm{DBH} \geq 10 \mathrm{~cm})$ & {$[\ln (\mathrm{AGB})=-1.716+2.413 \times \ln$} & $\begin{array}{c}\text { Adapted from (Nogueira } \\
\text { et al. 2008a) }\end{array}$ \\
Live palms $(\mathrm{DBH} \geq 10 \mathrm{~cm})$ & {$[\ln (\mathrm{AGB})=-3.3488+2.748 \times[\ln$} & $\begin{array}{c}\text { Adapted from (Goodman } \\
\text { et al. 2013) }\end{array}$ \\
$\begin{array}{l}\text { Standing dead trees }(\mathrm{DBH} \geq 10 \mathrm{~cm}) \\
\text { Crownless trees and dead palms }\end{array}$ & $\mathrm{AGB}=\mathrm{G} \times \mathrm{H} \times \beta 0 \times \mathrm{d} \times 0.1$ & Brown et al. 1995 \\
$(\mathrm{DBH} \geq 10 \mathrm{~cm})$ & $\mathrm{AGB}=\mathrm{G} \times \mathrm{H} \times \mathrm{F} \times \mathrm{d}$ & Graça et al. 1999 \\
Woody debris $(\mathrm{DBH} \geq 10 \mathrm{~cm})$ & Line-intercept transects & Van Wagner 1968 \\
Bamboo (live and dead) & Direct weighing & - \\
\hline
\end{tabular}

$A G B$ aboveground biomass (dry weight in $\mathrm{kg}$ ); $D B H$ diameter at breast height, measured $1.30 \mathrm{~m}$ above the ground or above any buttresses $(\mathrm{cm}) ; c$ species wood density correction coefficient for trees (wood density of the species divided by the mean wood density in the area, which for this part of Amazonia is $0.540 \mathrm{~g} \mathrm{~cm}^{-3}$ ) (Nogueira et al. 2008a); $p$ density correction coefficient for palms. Mean wood density $=0.488 \mathrm{~g} \mathrm{~cm}^{-3}$ (Chave et al. 2006); $G$ cross-sectional area $\left(\mathrm{cm}^{2}\right) ; H$ total height $(\mathrm{m}) ; \beta 0$ regression coefficient $(0.62) ; d$ density attributed to the decomposition phase $\left(\mathrm{g} \mathrm{cm}^{-3}\right) ; F$ form factor, or the ratio of the volume of a bole to the volume of a cylinder with the length of the bole and diameter of the $\mathrm{DBH}(0.78)$ tion" along the southern edge of the Amazon forest (Nogueira et al. 2008a), incorporating a density correction coefficient based on the ratio between the species wood density (Zanne et al. 2009) and the average value of $0.54 \mathrm{~g} \mathrm{~cm}^{-3}$ for wood density in this region (Nogueira et al. 2007). The same density correction coefficient was used to calculate the ratio between the palms species wood density and the average value of $0.488 \mathrm{~g} \mathrm{~cm}^{-3}$ for the family Arecaceae (Chave et al. 2006).

For species that did not have densities in the database, we used the mean density of the genus. In cases lacking a value for the genus, we used the average value for the family (Chave et al. 2006). The estimated dry biomass of each tree and palm individual was multiplied by the carbon concentrations of $50 \%$ and $49.4 \%$, respectively, in order to estimate carbon stock (Malhi et al. 2004; Goodman et al. 2013).

\subsubsection{Dead biomass (necromass)}

For each class of dead biomass, it was necessary to determine density values for the different phases of decomposition. The decomposition category was assigned in the field based on the classification proposed by Silva et al. (2016) (Appendix, Table 4).

After classification of the samples as a function of the decomposition phase, they were separated and weighed and their individual wet volumes were determined by the waterdisplacement method (Archimedes principle). Samples were in the form of cross-sectional disks in order to represent the radial variability in wood anatomy. The dry weights of the samples were obtained after air drying for a period of 15 days and the mean values for density of the samples in each of the three decomposition classes were used for estimating the biomass of standing dead trees, crownless trees, dead palms, and woody debris.

\subsubsection{Standing dead trees and palms}

Biomass of standing dead trees was quantified using the equation fit by Brown et al. (1995) at the Samuel ecological station (Rondônia) and adapted by Nascimento and Laurance (2006) when considering wood density. We discounted $10 \%$ of the calculated value due to the absence of leaves and branches (Delaney et al. 1998). Biomass of crownless trees and dead palms was estimated by the equation proposed by Graça et al. (1999), adopting a form factor of 0.78 (Fearnside 1992).

\subsubsection{Woody debris}

For estimation dead biomass in woody debris, we adapted the line-intercept method described by Van Wagner (1968). Three 20-m lines were placed in each plot and all pieces of woody debris with diameter above $10 \mathrm{~cm}$ that intercepted the line were sampled, with the exception of bamboo. The diameter of each piece was recorded at the point it intercepted the line. A water content of 0.416 was considered for woody debris (Nogueira et al. 2008b). To estimate the carbon stored by the woody debris, we adopted a carbon content of $46.4 \%$ (Graça et al. 1999).

\subsubsection{Guadua spp. biomass}

Biomass of bamboo was estimated by directly weighing all of the ramets found in each sampled subplot. After recording the number of established stems, all bamboo 
ramets were sectioned using the lateral ends of the subplots as cutting limits. Weighing was done in the field using a spring balance with a maximum capacity of $200 \mathrm{~kg}$ and precision of $1 \mathrm{~kg}$.

Samples of stems (live and dead) and of leaves (live and dead) were collected for determination of water content and density. The leaves were weighed separately from the culms, and live ramets were weighed separately from dead ones. The dry weight of each weighing was calculated by deducting the water content of each sampled compartment. For conversion of bamboo biomass to carbon stock, a carbon content of $50 \%$ was adopted as a default value for vegetation in general (Brown 1997).

\subsubsection{Data analysis}

Parametric statistical tests were applied to the analysis of variance (ANOVA) with 95\% confidence for determination of possible effects of the impact levels on the different biomass compartments. Evaluations of the homoscedasticity and the normality of the data were performed by the F-max of Hartley and Shapiro-Wilk tests, respectively (Hartley 1950; Shapiro and Wilk 1965). We conducted all of the analyses in R software (R Core Team 2018).

In cases of absence of homoscedasticity or normality in the data, transformation techniques (i.e., logarithmic transformation) were used in order to comply with the assumptions of ANOVA. The Kruskal-Wallis non-parametric statistical test was applied in cases where the data did not fit the ANOVA assumptions (Fig. 3).

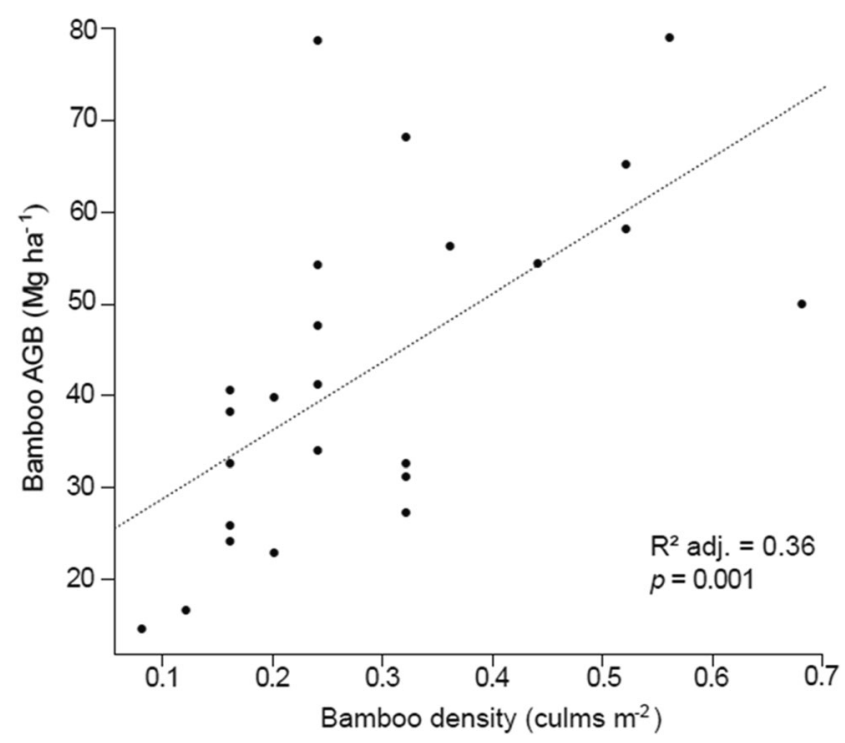

Fig. 4 Linear regression $\left(R^{2}=0.36, p=0.001\right)$ between aboveground biomass $\left(\mathrm{Mg} \mathrm{ha}^{-1}\right)$ of bamboo and culm density for all sample units in the study

\section{Results}

\subsection{Guadua spp. abundance}

Two measures of bamboo abundance were evaluated: aboveground biomass $\left(\mathrm{Mg} \mathrm{ha}^{-1}\right)$ and culm density per unit area (culms $\mathrm{m}^{-2}$ ). The relationship between these two variables was observed through a significant linear regression $\left(R^{2}=\right.$ $0.36 ; p=0.001$ ) (Fig. 4).

The average dry aboveground biomass (live + dead) of Guadua spp. was $27 \%$ higher in the treatment affected by fire when compared to the control (Table 2).
Fig. 3 Schematic of the conceptual framework of the study. Cylinders represent the sampled variables. Rounded rectangles represent the methodological approach and oval frames represent the analytical steps. Double arrows show the application of a linear regression model to observe the relationship between the two abundance variables for Guadua spp. (aboveground biomass and culm density). Color figure available in online version

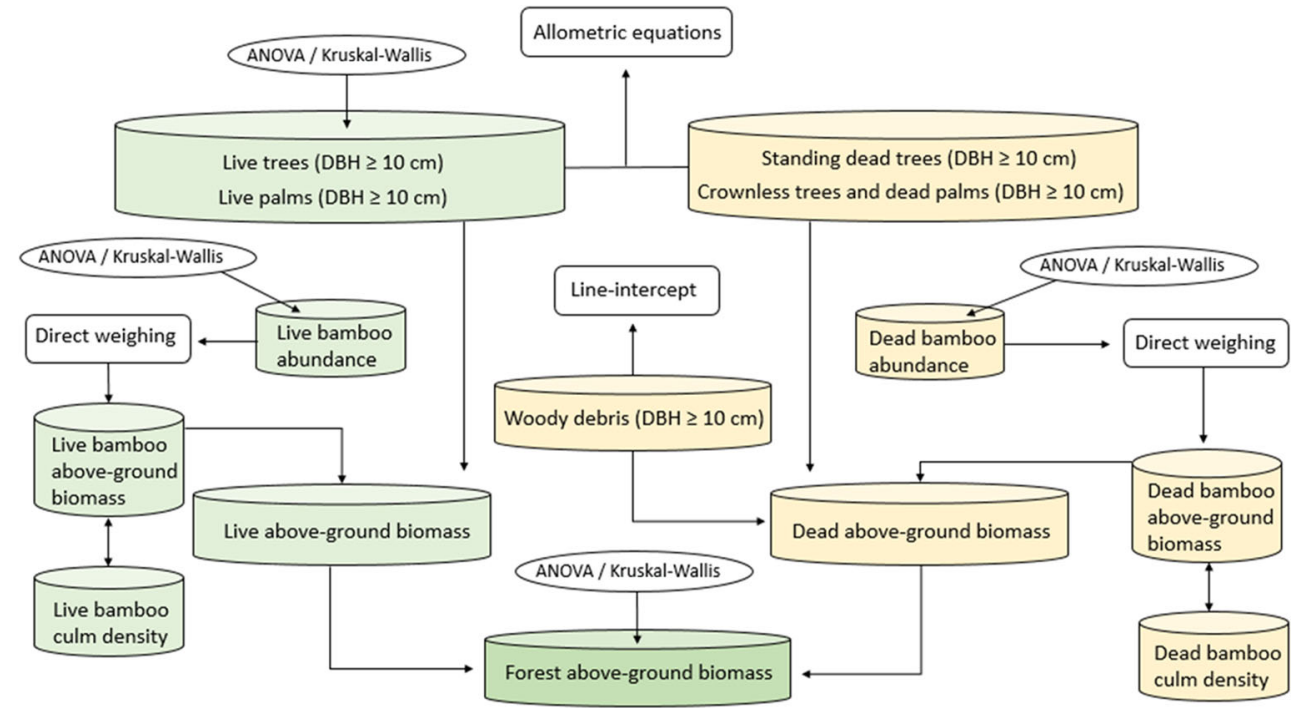


Table 2 Aboveground biomass (live + dead) of trees, palms, bamboo, and forest per hectare in the different treatments

\begin{tabular}{|c|c|c|c|c|c|}
\hline & Parameter & Control & Fire & Fire + logging & $p$ \\
\hline \multirow[t]{3}{*}{ Trees } & $\operatorname{Mean}\left(\mathrm{Mg} \mathrm{ha}^{-1}\right)$ & $215.0^{\mathrm{a}}$ & $105.4^{\mathrm{b}}$ & $122.3^{\mathrm{b}}$ & \multirow[t]{3}{*}{ ANOVA $0.012 *$} \\
\hline & $\mathrm{CV}(\%)$ & 40.9 & 39.5 & 63.1 & \\
\hline & CI & $141.4-288.7$ & $70.7-140.3$ & $57.7-186.8$ & \\
\hline \multirow[t]{4}{*}{ Palms } & $\operatorname{Mean}\left(\mathrm{Mg} \mathrm{ha}^{-1}\right)$ & 4.3 & 14.2 & 0.5 & \multirow[t]{3}{*}{ Kruskal-Wallis 0.19} \\
\hline & $\mathrm{CV}(\%)$ & 84.3 & 253.5 & 116.3 & \\
\hline & CI & $1.2-7.3$ & $0-44.2$ & $0.01-1.1$ & \\
\hline & Mean $\left(\mathrm{Mg} \mathrm{ha}^{-1}\right)$ & $219.3^{\mathrm{a}}$ & $119.7^{\mathrm{b}}$ & $122.8^{\mathrm{b}}$ & ANOVA \\
\hline \multirow[t]{3}{*}{ Trees + palms } & $\mathrm{CV}(\%)$ & 41.3 & 36.7 & 63.1 & \\
\hline & CI & $143.6-295.0$ & $86.0-156,3$ & $58.1-187.6$ & $0.019^{*}$ \\
\hline & Mean $\left(\mathrm{Mg} \mathrm{ha}^{-1}\right)$ & 38.26 & 48.66 & 41.91 & ANOVA \\
\hline \multirow[t]{3}{*}{ Bamboo } & $\mathrm{CV}(\%)$ & 44.2 & 33.2 & 52.7 & \\
\hline & CI & $24.12-52.40$ & $35.16-62.17$ & $23.44-60.38$ & 0.534 \\
\hline & $\operatorname{Mean}\left(\mathrm{Mg} \mathrm{ha}^{-1}\right)$ & $259.97 \mathrm{a}$ & $171.96 \mathrm{~b}$ & $167.34 \mathrm{~b}$ & ANOVA \\
\hline \multirow[t]{2}{*}{ Forest } & $\mathrm{CV}(\%)$ & 36.6 & 24.2 & 51.1 & \\
\hline & CI & $180.3-339.6$ & $137.0-206.9$ & $95.8-238.8$ & $0.045^{*}$ \\
\hline
\end{tabular}

Significant differences between treatments are indicated by different lower-case letters $(a$ and $b$ ) beside the means; $*=p<0.05$

$C V$ coefficient of variation; $C I$ confidence interval

As was observed in the case of aboveground biomass of bamboo, culm density per unit area was higher, on average, by $22 \%$ in the two treatments with fire compared to the control plots (Appendix, Table 5). Although an ecologically relevant difference between treatments has been found here, there is a high variability of aboveground biomass in this forest type.

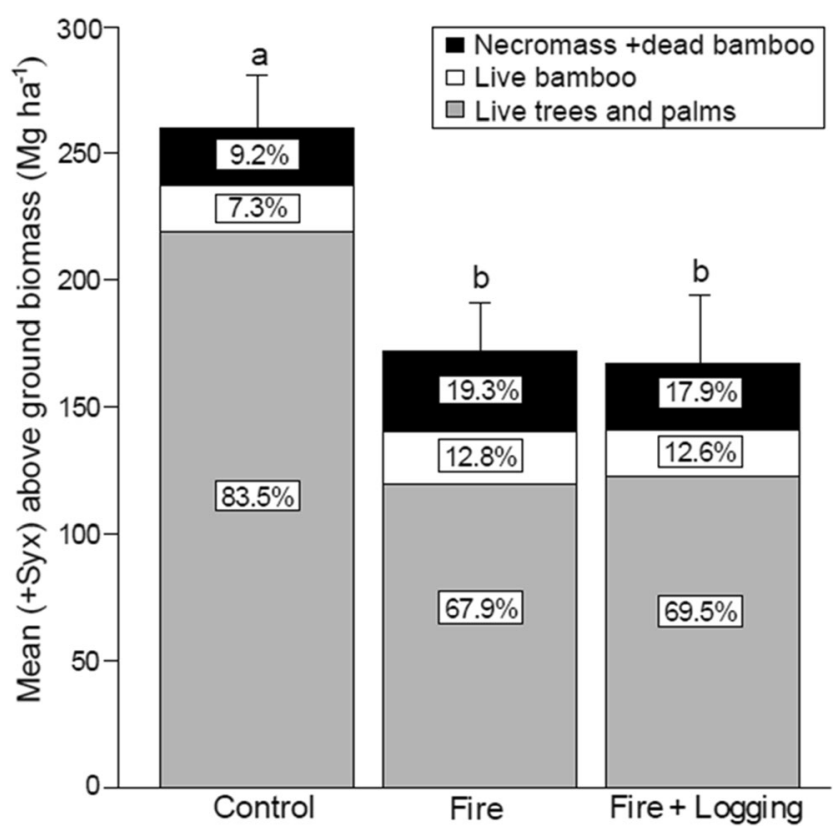

Fig. 5 Composition of the total (live + dead) aboveground biomass $\left(\mathrm{Mg} \mathrm{ha}^{-1}\right)$ of the forest for each treatment

\subsection{Forest biomass}

In addition to necromass, we sampled 1111 live trees $(\mathrm{DBH} \geq$ $10 \mathrm{~cm}), 105$ live palms ( $\mathrm{DBH} \geq 10 \mathrm{~cm})$, and 174 live and dead bamboos in the plots. The dry AGB (live + dead) of the forest was obtained by summing the values for all of the biomass classes sampled in the study. There was a significant difference $(p=0.045)$ between the control and the disturbed treatments (Table 2).

The classes that contributed most to the total amount of biomass (live + dead) were the live trees and palms, accounting for $83.5 \%$ of the total biomass in the control treatment. Considering all treatments, live trees and palms represented $77.1 \%$ of the total dry aboveground biomass of the forest (Fig. 5).

In terms of availability of combustible material, the largest amount of dead biomass was found in the treatment affected by fire, representing $17 \%$ of the total biomass in this treatment. Values for total dry aboveground biomass (live + dead) obtained in the control treatment $\left(259.97 \mathrm{Mg} \mathrm{ha}^{-1}\right)$, intermediate-impact treatment (171.96 $\left.\mathrm{Mg} \mathrm{ha}^{-1}\right)$, and highimpact treatment (167.34 $\mathrm{Mg} \mathrm{ha}^{-1}$ ) were converted to equivalent carbon stock values of $129.87 \mathrm{Mg} \mathrm{ha}^{-1}, 85.76 \mathrm{Mg} \mathrm{ha}^{-1}$, and $83.57 \mathrm{Mg} \mathrm{ha}^{-1}$, respectively.

\subsection{Biomass of live trees and palms}

The values for live-tree biomass showed a significant difference $(p=0.012)$ between the control and fire treatments. 

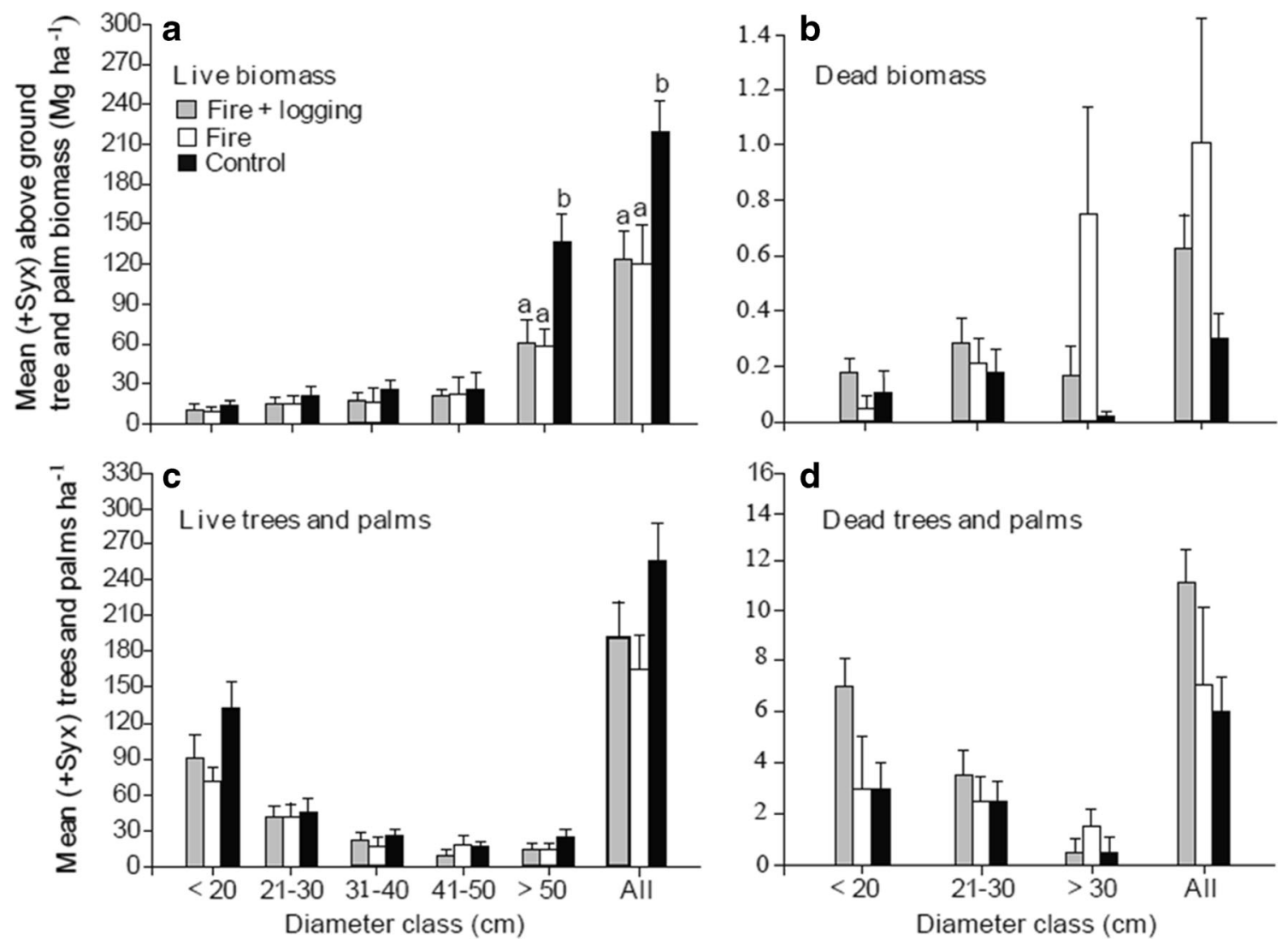

Fig. 6 Mean $\left(+\mathrm{S}_{\mathrm{yx}}\right)$ of the aboveground biomass in $\mathrm{Mg} \mathrm{ha}^{-1}(\mathbf{a}, \mathbf{b})$ and number $(\mathbf{c}, \mathbf{d})$ of live trees and palms per hectare by diameter class in the different treatments

This difference was detected from a Tukey test $(p<0.05)$ followed by application of ANOVA. In the case of biomass of live palms, absence of normality in the data, even after a logarithmic transformation, was shown by the ShapiroWilk test $(W=0.83, p=0.0001)$. This made application of the Kruskal-Wallis test necessary (Table 2). Considering the group formed by live trees and palms, more than half of the aboveground biomass $(53.7 \%)$ was composed of large individuals $(\mathrm{DBH}>50 \mathrm{~cm})$. Significant differences were observed for the aboveground biomass of live trees + palms $(p=0.019)$ and for the large individuals $(p=0.049)$. Using the Tukey test $(p<0.05)$ followed by ANOVA, differences were detected between the control and impact treatments (fire and fire + logging) (Fig. 6).

When considering the biomass of the group formed by live trees and palms, we observed proximity between the values obtained in the two treatments impacted by disturbances (Table 3).
Table 3 Mean ( \pm standard deviation) aboveground biomass $\left(\mathrm{Mg} \mathrm{ha}^{-1}\right)$ of live trees and palms

\begin{tabular}{lllll}
\hline Diameter class $(\mathrm{cm})$ & Control & Fire & Fire + logging & ANOVA $p$ \\
\hline$\leq 20$ & $13.35 \pm 6.1$ & $9.36 \pm 3.32$ & $9.97 \pm 7.51$ & $0.23^{* *}$ \\
$21-30$ & $20.05 \pm 8.46$ & $14.95 \pm 3.58$ & $15.3 \pm 6.74$ & $0.20^{*}$ \\
$31-40$ & $25.13 \pm 7.36$ & $15.41 \pm 9.76$ & $16.45 \pm 11.19$ & $0.09^{*}$ \\
$41-50$ & $25.36 \pm 12.05$ & $21.92 \pm 18.09$ & $20.68 \pm 20.79$ & $0.86^{*}$ \\
$>50$ & $135.43^{\mathrm{a}} \pm 85.85$ & $58.04^{\mathrm{b}} \pm 38.53$ & $60.40^{\mathrm{b}} \pm 57.48$ & $0.049^{* *}$ \\
Total & $219.3^{\mathrm{a}} \pm 90.54$ & $119.7^{\mathrm{b}} \pm 44.86$ & $122.8^{\mathrm{b}} \pm 72.29$ & $0.019^{*}$ \\
\hline
\end{tabular}

Significant differences between treatments are indicated by different lower-case letters ( $a$ and $b$ ) beside the means *ANOVA \& Tukey; ** Kruskal-Wallis \& Mann-Whitney $U$-test 


\section{Discussion}

\subsection{Bamboo-dominated forest and disturbances}

In this study, we show an increase in bamboo abundance, a significant decrease in large-tree aboveground biomass, and, consequently, in aboveground forest biomass following fire and post-burn logging. However, one must consider the high spatial variability in aboveground biomass and different potential responses of bamboo-dominated forests following anthropogenic disturbances. Fire occurrence in bamboo-dominated forests is $45 \%$ higher in dead than live bamboo populations during drought years, suggesting a potential process to the maintenance and expansion of bamboo in the forest (Dalagnol et al. 2018).

Considering the last 33 years (1984-2017), the years 2005, 2010, and 2016 had the highest frequencies and intensities of forest fires in the state of Acre, indicating a probable relation of these phenomena to the effects of a strong Atlantic dipole (2005), a strong Atlantic dipole together with a weak El Niño (2010), and a weak Atlantic dipole together with a strong El Niño (2016). Extreme events from both of these phenomena are increasing in frequency as a consequence of anthropogenic global warming (Meehl et al. 2007, p. 779; Cox et al. 2008; Evan et al. 2009).

In addition to climate change, direct human activities, such as logging, are also determinant factors for fire occurrence (Aragão et al. 2018). At least $46 \%$ of the total forest area impacted by forest fires in the state of Acre is located within settlement projects and at least $15 \%$ within governmentcreated conservation units, where theoretically there should be low human pressure (da Silva 2017).

\subsection{Guadua spp. abundance}

Although the relationship between the two abundance variables for Guadua spp. (aboveground biomass and culm density) in the present study was positive and linear, it was not very strong $\left(R^{2}=0.34\right)$. This relationship would be intuitive if all the ramets found in the sample units were fully sampled. However, the sampling method used the lateral extremities of the subplots as cutting limits of the culms in the biomass sampling.

Yavit (2017) found a nonlinear parabolic relationship between these two variables for Guadua spp. in southeastern Peru, where, after a certain point, further increase in bamboo density did not result in further increase in its biomass, instead leading to a reduction. One possible hypothesis that may explain this ecological mechanism is the lower density of trees in high bamboo density environments. In these scenarios, the culms lose their verticality, failing to access the forest canopy because they cannot rely on adjacent trees. Consequently, bamboos have their development limited by light, remaining thinner and shorter. However, the nonlinear pattern was not conclusive for our data set, where only one plot had high culm density with lower biomass, consistent with the nonlinear pattern (Appendix, Fig. 9).

Dead bamboo biomass was greater than live bamboo biomass for all treatments (Appendix, Fig. 7). A possible explanation for the large amount of dead biomass found in the current study may be tied to the end of the life cycle of the bamboo populations sampled. This condition was characterized in the field by the presence of abundant fruits (Appendix, Fig. 8), a condition that frequently precedes the periodic mass mortality event of bamboo populations (Janzen 1976; de Carvalho et al. 2013).

Biomass of Guadua spp. showed no significant difference between treatments. However, the intermediate-impact treatment (fire) had an average bamboo biomass more than $10 \mathrm{Mg} \mathrm{ha}^{-1}$ higher than the control treatment. In another area located $27 \mathrm{~km}$ from the city of Rio Branco and near the site of the current study, Torezan and Silveira (2000) reported only $10.2 \mathrm{Mg} \mathrm{ha}^{-1}$ of bamboo biomass, which is approximately 4 times lower than the mean value in the present study. In addition, the authors reported that the biomass of Guadua spp. represented $4.2 \%$ of the total forest biomass, while in the current study the corresponding value is $21.5 \%$. Considering that the bamboo ramets sampled in both studies belonged to the same population and that the mass-flowering event was observed in 2016, a natural increase of bamboo biomass was expected due to ripening of culms and establishment of new ramets.

The mean value for aboveground biomass found by Yavit (2017) for Guadua spp. was $6.2 \mathrm{Mg} \mathrm{ha}^{-1}$ in areas located in the departments of Madre de Dios and Ucayali, Peru. This value was six times lower than the mean value of $38.26 \mathrm{Mg} \mathrm{ha}^{-1}$ for undisturbed plots in the current study.

Considering all treatments, the average biomass of Guadua spp. in our study (42.96 $\mathrm{Mg} \mathrm{ha}^{-1}$ ) represented $29.1 \%$ of the biomass of living trees $\left(147.61 \mathrm{Mg} \mathrm{ha}^{-1}\right)$. The largest arboreal individual of the current study found in the control treatment was a Calophyllum brasiliensis (Guanandi) with $133.7 \mathrm{~cm}$ DBH. The biomass estimated for this single individual was 26.1 Mg, which represents more than half of the estimated mean biomass of Guadua spp. per hectare. This suggests high uncertainty for the tree component in the absence of a much larger sample size, and therefore also implies high uncertainty for values for bamboo when expressed as percentages of either tree or total biomass.

With respect to the dominance of bamboo, the mean values for the control treatment $\left(2500\right.$ culms ha $\left.^{-1}\right)$, the intermediateimpact treatment ( 3400 culms ha $^{-1}$ ), and the high-impact treatment $\left(2700\right.$ culms ha $\left.^{-1}\right)$ can all be considered high in relation to the values reported by Barlow et al. (2012) in Acre's Chico Mendes Extractive Reserve (RESEX), where there were 279.7 culms ha ${ }^{-1}$ in forest with no known impact and 282.2 
culms ha ${ }^{-1}$ after forest-fire disturbance. The values in the present study were also higher than the 1420 culms ha $^{-1}$ found by Torezan and Silveira (2000) in an area near our study site, and the 1350 culms ha ${ }^{-1}$ reported by Yavit (2017) in southeastern Peru. The bamboo densities that are closest to those found in this study were reported by Griscom and Ashton (2006) on the Tambopata River in Peru, with $3860 \pm 265$ culms ha $^{-1}$ in forests dominated by Guadua weberbaueri and $2375 \pm 618 \mathrm{culms} \mathrm{ha}^{-1}$ in forests dominated by Guadua sacocarpa.

\subsection{Aboveground forest biomass}

Since Amazon forest has great structural and floristic heterogeneity, a high variability in forest biomass is expected, even for plots in the same forest type (Fearnside 2018). Although the soils under forests in southwestern Amazonia have relatively high concentrations of phosphorus by Amazonian standards (Quesada et al. 2010), the biomass values can be considered low compared to values observed in other parts of the Brazilian Amazon (Nogueira et al. 2015). This can be explained by high tree turnover, which follows a decreasing gradient from west to east in the Amazon (Quesada et al. 2012) and implies high recruitment and mortality rates. A reduced residence time can be expected for carbon in the forests in the area of the present study.

The legacy left by impacts associated with these forests could be observed in our study more than 10 years after disturbance. The difference between the carbon stored in 1 ha of the control treatment and in the treatment with the highest impact was $46.3 \mathrm{Mg} \mathrm{ha}^{-1}$. This amount is equivalent to the emissions from the annual consumption of goods and services by approximately 17 Brazilians, 19 Peruvians, or 25 Bolivians in 2015 (Le Quéré et al. 2015).

\subsection{Biomass of live trees and palms}

The biomass class of live trees and palms represented, on average, $74 \%$ of the total aboveground biomass (live + dead). Thus, the reduction of aboveground biomass value in the forest can be largely attributed to the reduction in the number of live trees and palms per hectare following disturbance (Fig. 5). A large part of the high aboveground biomass found in the undisturbed treatment can be attributed to the concentration of individuals in the highest diameter class (Fig. 6).

Although the treatment with the highest impact had more trees and palms per hectare than the treatment with intermediate impact, the latter had a larger number of individuals with $\mathrm{DBH}>40 \mathrm{~cm}$, which was reflected by a higher biomass value of live trees and palms (Fig. 6). The biomass of live trees and palms with DBH above $40 \mathrm{~cm}$ represented, on average, $70 \%$ of the biomass of live trees and palms in all diameter classes, and $54 \%$ of the total aboveground biomass of the forest (live + dead), indicating the great importance that maintaining these individuals has for the forest carbon stock.

Considering only live trees and palms with $\mathrm{DBH}>50 \mathrm{~cm}$, it was possible to observe a significant difference for biomass values between treatments $(p=0.049)$. The control treatment had a mean value $55.4 \%$ higher than the treatment with logging and fire and $57.1 \%$ higher than the treatment impacted only by fire (Table 3).

The values for biomass of live trees and palms (DBH > $10 \mathrm{~cm}$ ) sampled by Barlow et al. (2012) 3 years after a fire in Acre were higher than those obtained in the present study for the forest without known impact ( 380 to $400 \mathrm{Mg} \mathrm{ha}^{-1}$ ) and for the forest affected by fire (260 to $280 \mathrm{Mg} \mathrm{ha}^{-1}$ ). There is evidence for a structural difference in the abundance of senescent large trees in the Amazon along a gradient from east to west, with older individuals being more abundant in the eastern Amazon region (Chao et al. 2008). In addition, studies also suggest a possible difference in the mortality dynamics of these large trees along this same gradient (Chao et al. 2008; Phillips et al. 2008). Large trees are also most sensitive to dry conditions from edge effects (Nascimento and Laurance 2004) and from experimental drought (Nepstad et al. 2007). Assuming that senescent large trees are more vulnerable to stress from drought (as well as disturbances from logging and fire) than are smaller trees, large trees in the southwestern Amazon would be more resistant to anthropogenic impacts than trees of similar diameter in eastern Amazonia because they are less senescent (Barlow et al. 2012). The data from the present study, however, reveal a high vulnerability of large trees to these disturbances, given the observation of a subtle reduction in the number of live trees and palms with $\mathrm{DBH}>$ $50 \mathrm{~cm}$ (Fig. 6), which represented a reduction of $45.4 \%$ in the biomass of the intermediate-impact treatment and $44.0 \%$ in the biomass of the treatment with the greatest impact (Table 3).

\subsection{Bamboo-dominated forest, ecosystem services, and potential for management}

The "cascade model" of ecosystem service generation presented in 2010 by Haines-Young and Potschin (2010) suggests a link between ecosystem services and human well-being. Despite the difficulty of defining and measuring ecosystem services, assigning a value to services provided by conserved forest is important for discussion and planning of public policies for conservation (Potschin and Haines-Young 2016), such as reducing emissions from deforestation and forest degradation (REDD+) (Fearnside 2012).

A complete cycle of generating and managing ecosystem services can be implemented by integrating public and private 
interests into planning and decision-making processes (Spangenberg et al. 2014). Because large trees are of central importance both for carbon stock and for the forest's value for timber management, the impact on these trees due to the increase of bamboo in conjunction with forest fires is both an environmental and a commercial concern.

\section{Conclusions}

This study suggests a downward trend in the aboveground carbon stock of the forest with increasing level of impact. Reduction in the aboveground biomass of live trees and palms, especially in the diameter class over $50 \mathrm{~cm}$, is one of the main consequences related to disturbances in open forests dominated by bamboo. These individuals are of central importance for the carbon stock, and, from the economic point of view, decrease in their abundance leads to a loss of value of the standing forest, reducing the already-low potential of these forests for management.

The damage to Brazil's Amazon forest initiated by the 2005 drought, documented here, adds one more piece of evidence of the need to contain global climate change and of the logic for Brazil to assume a leading role in these efforts.

Acknowledgments We thank the National Institute for Research in Amazonia (INPA: PRJ15.125), the National Institute of Science and Technology for the Environmental Services of Amazonia (INCT-SERVAMB), the National Council for Scientific and Technological Development (CNPq/PCI Program Proc. 304130/ 2013-3 and 301183/2015-5; CNPq: Proc. 304020/2010-9; 573810/2008-7), and the Foundation for Support of Research in Amazonas State (FAPEAM: Proc. 708565) for logistical support. We owe personal thanks to Sebastião Mota, Evandro Ferreira, Marcos Vinícos D’Oliveira, Aurora Miho Yanai, Jochen Schöngart, Reinaldo Imbrózio Barbosa, Nathan B. Gonçalves, and Bruce W. Nelson.

Statement on data availability The datasets generated and/or analyzed during the current study are available in the Zenodo repository (Ziccardi et al. 2019) at https://doi.org/10.5281/zenodo.3530726

Funding information This study received financial support from National Institute for Research in Amazonia (INPA: PRJ15.125), the National Institute of Science and Technology for the Environmental Services of Amazonia (INCT-SERVAMB), the National Council for Scientific and Technological Development (CNPq/PCI Program Proc. 304130/2013-3 and 301183/2015-5; CNPq: Proc. 304020/2010-9; 573810/2008-7), and the Foundation for Support of Research in Amazonas State (FAPEAM: Proc. 708565). This article is a contribution of the Brazilian Research Network on Global Climate Change, FINEP/ Rede CLIMA Grant Number 01.13.0353-00.

\section{Compliance with ethical standards}

Conflict of interest The authors declare that they have no conflict of interest.

Disclaimer The funding sponsors had no role in the design of the study, in the collection, analyses do, or interpretation of data, in the writing of the manuscript, and in the decision to publish the results.

\section{Appendix}

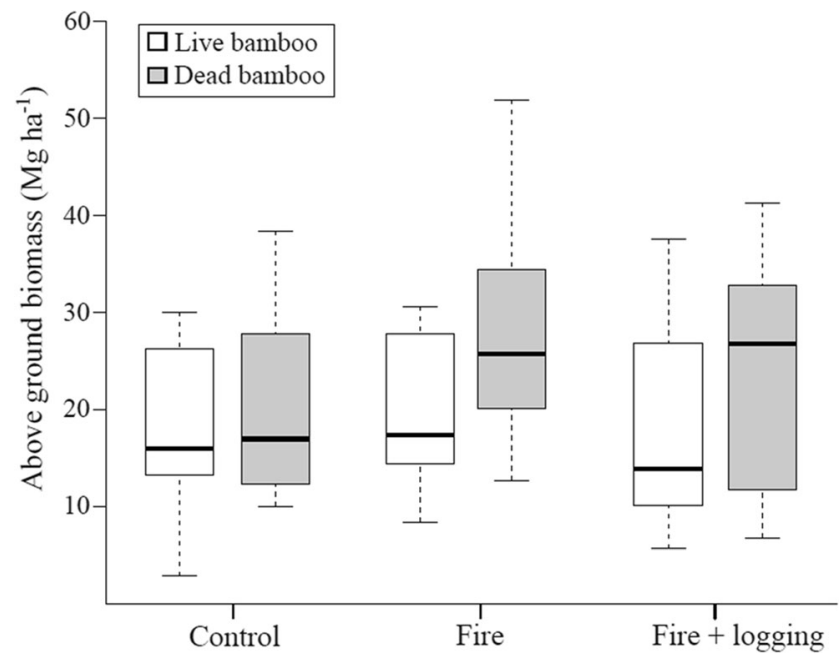

Fig. 7 Dry aboveground biomass of live and dead bamboo per hectare
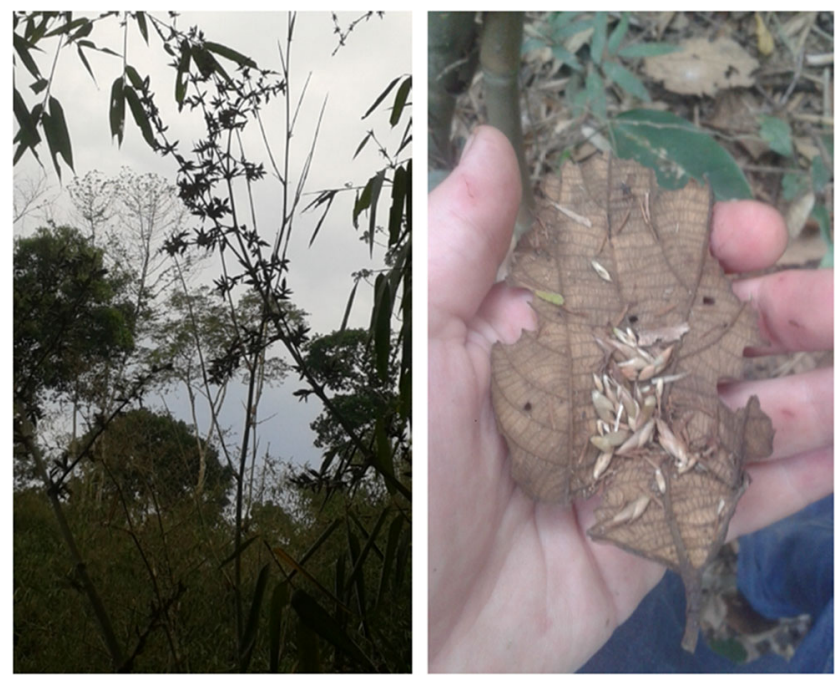

Fig. 8 Abundance of fruits and seeds of Guadua spp. observed in the field, indicating a mass-flowering event 


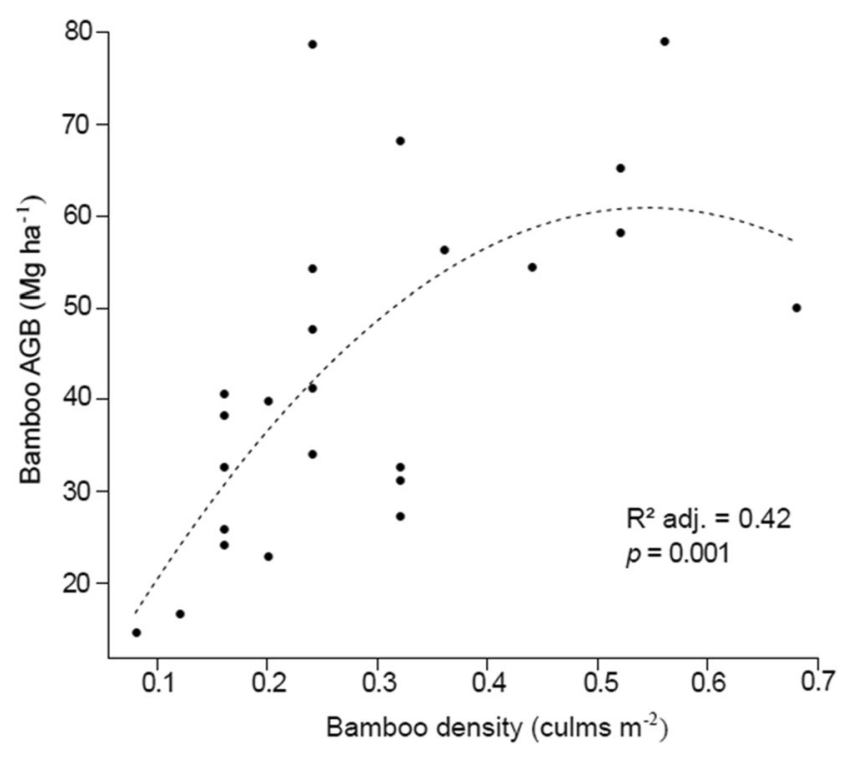

Fig. 9 Nonlinear regression between bamboo aboveground biomass (AGB) and bamboo density for all sample units

Table 4 Characteristic of woody debris related to the phases of wood decomposition

\begin{tabular}{ll}
\hline $\begin{array}{l}\text { Phase of } \\
\text { decomposition }\end{array}$ & Description of characteristics \\
\hline $\mathrm{C} 1$ & $\begin{array}{l}\text { Woody debris without noticeable deterioration, recently fallen and resistant to attack by } \\
\text { microorganisms } \\
\text { Woody debris with few signs of fungal or insect attack, with initial deterioration } \\
\text { C2 } 3\end{array}$ \\
$\begin{array}{l}\text { Woody debris at an advanced stage of deterioration, easily breaking or cracking if } \\
\text { touched }\end{array}$ \\
\hline
\end{tabular}

Table 5 Guadua spp. density in the different treatments

\begin{tabular}{lllll}
\hline Treatment & Mean density $\left(\right.$ culms ha $\left.^{-1}\right)$ & CV $(\%)$ & Percentage error $(\%)$ & $p$ (ANOVA) \\
\hline Control & 2500 & 45.9 & 38.4 & 0.478 \\
Fire & 3400 & 50.3 & 42.1 & \\
Fire + logging & 2700 & 63.2 & 52.9 & \\
\hline
\end{tabular}

$C V$ coefficient of variation

\section{References}

Acre, Governo do Estado (2000) Programa Estadual de Zoneamento Ecológico-Econômico do Estado do Acre. Zoneamento EcológicoEconômico: Recursos Naturais e Meio Ambiente - Documento Final. Rio Branco: SECTMA 1:15-35 https://www.amazonia. cnptia.embrapa.br/publicacoes estados/Acre/Fase\%201/Vol.201 Recursos_Naturais_e_Meio_Ambiente.pdf
Aragão LE, Anderson LO, Fonseca MG, Rosan TM, Vedovato LB, Wagner FH, Silva CVJ, Junior CHL, Araí E, Aguiar A, Barlow J, Berenguer E, Deeter M, Domingues LG, Gatti L, Gloor M, Malhi Y, Marengo J, Miller J, Philips OL, Barlow J (2018) 21st century drought-related fires counteract the decline of Amazon deforestation carbon emissions. Nat Commun 9(1):536

Barlow J, Silveira JM, Mestre LA, Andrade RB, D'Andrea GC, Louzada J, Vaz-de-Melo FZ, Numata I, Lacau S, Cochrane MA (2012) 
Wildfires in bamboo-dominated Amazonian forest: impacts on aboveground biomass and biodiversity. PLoS One 7(3):art. e33373. https://doi.org/10.1371/annotation/8013f95e-71f4-4ec0afe9-00cea6627685

Brazil, IBGE (Instituto Brasileiro de Geografia e Estatística). (2017). Diretoria de Pesquisas, Coordenação de População e Indicadores Sociais, Estimativas da população residente com data de referência $1^{\circ}$ de julho de 2017. Accessed 12 Feb. 2018 https://cidades.ibge. gov.br/xtras/perfil.php?lang=\&codmun=120040\&search=acre|riobranco

Brown S (1997) Estimating biomass and biomass change of tropical forests: a primer. FAO Forestry Paper 134, Rome, Italy

Brown IF, Martinelli LA, Thomas WW, Moreira MZ, Ferreira CC, Victoria RA (1995) Uncertainty in the biomass of Amazonian forests: an example from Rondônia, Brazil. For Ecology and Management 75(1):175-189. https://doi.org/10.1016/03781127(94)03512-U

Chao KJ, Phillips OL, Gloor E, Monteagudo A, Torres-Lezama A, Martínez RV (2008) Growth and wood density predict tree mortality in Amazon forests. J Ecol 96(2):281-292. https://doi.org/10.1111/j. 1365-2745.2007.01343.x

Chave J, Muller-Landau HC, Baker TR, Easdale TA, Steege HT, Webb CO (2006) Regional and phylogenetic variation of wood density across 2456 Neotropical tree species. Ecol Appl 16(6):2356-2367. https://doi.org/10.1890/1051-0761(2006)016[2356:RAPVOW]2.0. $\mathrm{CO} ; 2$

Cox PM, Harris PP, Huntingford C, Betts RA, Collins M, Jones CD, Jupp TE, Marengo JA, Nobre CA (2008) Increasing risk of Amazonian drought due to decreasing aerosol pollution. Nature 45:212-215. https://doi.org/10.1038/nature06960

d'Oliveira MVN, de Guarino ES, Oliveira LC, Ribas LA, Acuña MHA (2013) Can forest management be sustainable in a bamboo dominated forest? A 12-year study of forest dynamics in western Amazon. Forest Ecology and Management 310:672-679. https:// doi.org/10.1016/j.foreco.2013.09.008

da Silva SS (2017) Dinâmica dos incêndios florestais no estado do Acre. Dissertation, National Institute for Research in Amazonia https:// bdtd.inpa.gov.br/handle/tede/2386

da Silva SS, Fearnside PM, Graça PMLA, Brown IF, Alencar A, de Melo AWF (2018) Dynamics of forest fires in the southwestern Amazon. For Ecol Manag 424:312-322. https://doi.org/10.1016/j.foreco. 2018.04.041

Daily GC (1997) Nature's services. Island Press, Washington, DC

Dalagnol R, Wagner F H, Galvão L S, Nelson B W, de Aragão L E O C (2018). Life cycle of bamboo in the southwestern Amazon and its relation to fire events. Biogeosciences 15(20): 6087-6104. doi.org/ 10.5194/bg-15-6087-2018

de Carvalho A L, Nelson B W, Bianchini M C, Plagnol D, Kuplich T M, Daly D C. (2013). Bamboo-dominated forests of the southwest Amazon: detection, spatial extent, life cycle length and flowering waves. PloS One 8(1): art. e54852. https://doi.org/10.1371/journal. pone. 0054852

Delaney M, Brown S, Lugo AE, Torres-Lezama A, Quintero NB (1998) The quantity and turnover of dead wood in permanent forest plots in six life zones of Venezuela. Biotropica 30(1):2-11. https://doi.org/ 10.1111/j.1744-7429.1998.tb00364.x

Evan AT, Vimont DJ, Heidinger AK, Kossin JP, Bennartz R (2009) The role of aerosols in the evolution of tropical North Atlantic Ocean temperature anomalies. Science 324:778-781. https://doi.org/10. 1126/science. 1167404

Fearnside PM (1990) Fire in the tropical rain forest of the Amazon basin. In: Goldammer JG (ed) Fire in the tropical biota. Springer, Berlin \& Heidelberg, Germany, pp 106-116. https://doi.org/10.1007/978-3642-75395-4 7

Fearnside PM (1992) Forest biomass in Brazilian Amazonia: comments on the estimate by Brown and Lugo. Interciência 17(1):19-27
Fearnside PM (2012) Brazil's Amazon forest in mitigating global warming: unresolved controversies. Clim Pol 12(1):70-81. https:// doi.org/10.1080/14693062.2011.581571

Fearnside PM (2018) Brazil's Amazonian forest carbon: the key to southern Amazonia's significance for global climate. Reg Environ Chang 18(1):47-61. https://doi.org/10.1007/s10113-016-1007-2

Ferrante L, Fearnside PM (2019) Brazil's new president and "ruralists" threaten Amazonia's environment, traditional peoples and the global climate. Environ Conserv. https://doi.org/10.1017/ S0376892919000213

Ferreira EJL (2014) O bambu é um desafio para a conservação e o manejo de florestas no sudoeste da Amazônia. Ciência e Cultura 66(3):46$51 \mathrm{http}: / /$ cienciaecultura.bvs.br/scielo.php?pid=S0009$67252014000300015 \&$ script=sci arttext

Goodman RC, Phillips OL, del Castillo TD, Freitas L, Cortese ST, Monteagudo A, Baker TR (2013) Amazon palm biomass and allometry. For Ecol Manag 310:994-1004. https://doi.org/10.1016/j. foreco.2013.09.045

Graça PMLA, Fearnside PM, Cerri CC (1999) Burning of Amazonian forest in Ariquemes, Rondônia, Brazil: biomass, charcoal formation and burning efficiency. For Ecol Manag 120(1-3):179-191. https:// doi.org/10.1016/S0378-1127(98)00547-7

Griscom BW, Ashton PMS (2006) A self-perpetuating bamboo disturbance cycle in a Neotropical forest. J Trop Ecol 22(5):587-597. https://doi.org/10.1017/S0266467406003361

Haines-Young R, Potschin M (2010) The links between biodiversity, ecosystem services and human well-being. Ecosystem Ecology: a new synthesis 1:110-139. https://doi.org/10.1017/ CBO9780511750458.007

Hartley HO (1950) The Maximum F-Ratio as a Short-Cut Test for Heterogeneity of Variance. Biometrika 37(3/4):308

Janzen DH (1976) Why bamboos wait so long to flower. Annu Rev Ecol Syst 7:347-391. https://doi.org/10.1146/annurev.es.07.110176. 002023

Le Quéré C, Moriarty R, Andrew RM, Peters GP, Ciais P, Friedlingstein P, Boden TA (2015) Global carbon budget 2014. Earth System Science Data 7(1):47-85. https://doi.org/10.5194/essd-7-47-2015

Lewis SL, Brando PM, Phillips OL, van der Heijden GM, Nepstad D (2011) The 2010 Amazon drought. Science 331(6017):554-554. https://doi.org/10.1126/science.1200807

Malhi Y, Baker TR, Phillips OL, Almeida S, Alvarez E, Arroyo L, Killeen TJ (2004) The above-ground coarse wood productivity of 104 Neotropical forest plots. Glob Chang Biol 10(5):563-591. https:// doi.org/10.1111/j.1529-8817.2003.00778.x

Meehl GA, Stocker TF, Collins WD, Friedlingstein P, Gaye AT, Gregory JM, Kitoh A, Knutti R, Murphy JM, Noda A, Raper SCB, Watterson IG, Weaver AJ, Zhao ZC (2007) Global climate projections. In: Solomon S, Qin D, Manning M, Chen Z, Marquis M, Averyt KB, Tignor M, Miller HL (eds) Climate change 2007: the physical science basis. Contribution of Working Group to the Fourth Assessment Report of the Intergovernmental Panel on Climate Change. Cambridge University Press, Cambridge, pp 747-845 https://www.ipcc.ch/publications_and_data/ar4/wg1/en/ch10.html

Molina C M C, Galiana-Martín L (2016) Fire scenarios in Spain: a territorial approach to proactive fire management in the context of global change. Forests 7(11): art. 273. https://doi.org/10.3390/f7110273

Nascimento HEM, Laurance WF (2004) Biomass dynamics in Amazonian forest fragments. Ecol Appl 14(3):S127-S138. https:// doi.org/10.1890/01-6003

Nascimento HE, Laurance WF (2006) Efeitos de área e de borda sobre a estrutura florestal em fragmentos de floresta de terra-firme após 1317 anos de isolamento [ffects of area and of edges on forest structure in fragments of terra firme forest after 13-17 years of isolation]. Acta Amazon 36(2):183-192. https://doi.org/10.1590/S004459672006000200008 
Nelson B W, Oliveira A C A, Batista G T, Vidalenc D, Silveira M (2001) Modeling biomass of forests in the southwest Amazon by polar ordination of Landsat TM. In Proceedings, Tenth Brazilian Remote Sensing Symposium. Foz de Iguaçu, Paraná, São José dos Campos, SP, Brazil: INPE. pp. 1683-1690

Nepstad DC, Verssimo A, Alencar A, Nobre C, Lima E, Lefebvre P, Schlesinger P, Potter C, Moutinho P, Mendoza E, Cochrane M (1999) Large-scale impoverishment of Amazonian forests by logging and fire. Nature 398:505-508. https://doi.org/10.1038/19066

Nepstad DC, Tohver IM, Ray D, Moutinho P, Cardinot G (2007) Mortality of large trees and lianas following experimental drought in an Amazon forest. Ecology 88(9):2259-2269. https://doi.org/10. 1890/06-1046.1

Nogueira EM, Fearnside PM, Nelson BW, França MB (2007) Wood density in forests of Brazil's 'arc of deforestation': implications for biomass and flux of carbon from land-use change in Amazonia. For Ecol Manag 248(3):119-135. https://doi.org/10.1016/j.foreco.2007. 04.047

Nogueira EM, Fearnside PM, Nelson BW, Barbosa RI, Keizer EWH (2008a) Estimates of forest biomass in the Brazilian Amazon: new allometric equations and adjustments to biomass from wood-volume inventories. For Ecol Manag 256(11):1853-1867. https://doi.org/10. 1016/j.foreco.2008.07.022

Nogueira EM, Fearnside PM, Nelson BW (2008b) Normalization of wood density in biomass estimates of Amazon forests. For Ecol Manag 256(5):990-996. https://doi.org/10.1016/j.foreco.2008.07. 022

Nogueira EM, Yanai AM, Fonseca FO, Fearnside PM (2015) Carbon stock loss from deforestation through 2013 in Brazilian Amazonia. Glob Chang Biol 21(3):1271-1292. https://doi.org/10.1111/gcb. 12798

Oliveira A C A (2000) Efeitos do bambu Guadua weberbaueri Pilger sobre a fisionomia e estrutura de uma floresta no sudoeste da Amazônia. Masters Thesis in Ecology, Manaus, Amazonas, Brazil: INPA/UA. $103 \mathrm{pp}$.

Phillips OL, Lewis SL, Baker TR, Chao KJ, Higuchi N (2008) The changing Amazon forest. Philosophical Transactions of the Royal Society of London B: Biological Sciences 363(1498):1819-1827. https://doi.org/10.1098/rstb.2007.0033

Potschin M, Haines-Young R (2016) Defining and measuring ecosystem services. In Routledge Handbook of Ecosystem Services (pp. 25-44). Routledge, Taylor \& Francis Group, London; New York. https://doi. org/10.4324/9781315775302

Quesada CA, Lloyd J, Schwarz M, Patião S, Baker TR, Czimczik C, Santos AJ (2010) Variations in chemical and physical properties of Amazon forest soils in relation to their genesis. Biogeosciences 7(5): 1515-1541. https://doi.org/10.5194/bg-7-1515-2010

Quesada CA, Phillips OL, Schwarz M, Czimczik CI, Baker TR, Patiño S, Fyllas NM, Hodnett MG, Herrera R, Almeida S, Alvarez Dávila E, Arneth A, Arroyo L, Chao KJ, Dezzeo N, Erwin T, Di Fiore A, Higuchi N, Honorio Coronado E, Jimenez EM, Killeen T, Lezama AT, Lloyd G, López-González G, Luizão FJ, Malhi Y, Monteagudo A, Neill DA, Núñez Vargas P, Paiva R, Peacock J, Peñuela MC, Peña Cruz A, Pitman N, Priante Filho N, Prieto A, Ramírez H, Rudas A, Salomão R, Santos AJB, Schmerler J, Silva N, Silveira M, Vásquez R, Vieira I, Terborgh J, Lloyd J (2012) Basin-wide variations in Amazon forest structure and function are mediated by both soils and climate. Biogeosciences 9:2203-2246. https://doi. org/10.5194/bg-9-2203-2012
R Core Team (2018). R: A language and environment for statistical computing. R Foundation for Statistical Computing, Vienna, Austria. https://www.R-project.org/.

Rockwell CA, Kainer KA, d'Oliveira MVN, Staudhammer CL, Baraloto C (2014) Logging in bamboo-dominated forests in southwestern Amazonia: caveats and opportunities for smallholder forest management. For Ecol Manag 315:202-210. https://doi.org/10.1016/j. foreco.2013.12.022

Shapiro SS, Wilk MB (1965) An Analysis of Variance Test for Normality (Complete Samples). Biometrika 52(3/4):591

Silva LFSG, de Castilho CV, de Oliveira CC, Pimentel TP, Fearnside PM, Barbosa RI (2016) Production and stock of coarse woody debris across a hydro-edaphic gradient of oligotrophic forests in the northern Brazilian Amazon. For Ecol Manag 364:1-9. https://doi.org/10. 1016/j.foreco.2015.12.045

Silveira M (2005) A floresta aberta com bambu no sudoeste da Amazônia: Padrões e processos em múltiplas escalas. [The open bamboo forest in southwest Amazonia: patterns and processes on multiple scales]. Rio Branco: Edufac. 127 pp.

Smith M, Nelson BW (2011) Fire favours expansion of bamboodominated forests in the south-west Amazon. J Trop Ecol 27(1): 59-64. https://doi.org/10.1017/S026646741000057X

Sombroek W (2001) Spatial and temporal patterns of Amazon rainfall: consequences for the planning of agricultural occupation and the protection of primary forests. Ambio 30(7):388-396. https://doi. org/10.1579/0044-7447-30.7.388

Spangenberg JH, von Haaren C, Settele J (2014) The ecosystem service cascade: further developing the metaphor. Integrating societal processes to accommodate social processes and planning, and the case of bioenergy. Ecol Econ 104:22-32

Torezan JMD, Silveira M (2000) The biomass of bamboo (Guadua weberbaueri Pilger) in open forest of the southwestern Amazon. Ecotropica 6(1):71-76

Van Wagner CE (1968) The line intersect method in forest fuel sampling. For Sci 14(1):20-26

Vasconcelos SS, Fearnside PM, Graça PMLA, Nogueira EM, Oliveira LC, Figueiredo EO (2013) Forest fires in southwestern Brazilian Amazonia: Estimates of area and potential carbon emissions. Forest Ecology and Management 291:199-208. https://doi.org/10. 1016/j.foreco.2012.11.044

Veldman JW, Putz FE (2011) Grass-dominated vegetation, not speciesdiverse natural savanna, replaces degraded tropical forests on the southern edge of the Amazon Basin. Biol Conserv 144:1419 1429. https://doi.org/10.1016/j.biocon.2011.01.011

Yavit N M (2017) Allometric derivation and estimation of Guadua weberbaueri and G. sarcocarpa biomass in the bamboodominated forests of SW Amazonia. bioRxiv, preprint: 129262. https://doi.org/10.1101/129262

Zanne A E, Lopez-Gonzalez G, Coomes D A, Ilic J, Jansen S, Lewis S L, Miller R B, Swenson N G, Wiemann M C, Chave J (2009) Global wood density database. http://datadryad.org/resource/doi:10.5061/ dryad.23

Ziccardi L, Graça P M L A, Figueiredo E O, Fearnside P M (2019) Data set (2016) Bamboo-dominated forest in Amazonia. V1. Zenodo. [Dataset]. https://doi.org/10.5281/zenodo.3530726

Publisher's note Springer Nature remains neutral with regard to jurisdictional claims in published maps and institutional affiliations. 